\title{
Digitalization of companies - the basis of regions' competitive development
}

\author{
Ekaterina Limonova \\ Department of Economic Security \\ Saratov Socio-Economic Institute \\ Plekhanov Russian University of Economics, \\ Saratov, Russia \\ E-mail: limonovaev@bk.ru
}

\author{
Anastasiya Domnicheva \\ Department of Economic Security \\ Saratov Socio-Economic Institute \\ Plekhanov Russian University of Economics, \\ Saratov, Russia \\ E-mail: nv.ukolova@yandex.ru
}

\author{
Irina Manakhova \\ Department of Economic Security \\ Saratov Socio-Economic Institute \\ Plekhanov Russian University of Economics, \\ Saratov, Russia \\ E-mail: ManakhovaIV@ mail.ru
}

\begin{abstract}
The article deals with the development of the digital economy in Russia, the problems of digitalization of companies in the context of the rapid development of information and computer technologies. The stage-by-stage transformation of the country into an information society is being investigated on the basis of introduction of new technologies and platforms using the aggregate index of the development of information and communication technologies. The most important directions of digital transformation of companies, factors influencing this process in the conditions of modern economy are being analyzed.
\end{abstract}

Keywords- information society, digital company, directions of companies' digitalization, Biesiot indicator

\section{INTRODUCTION}

The current level of development of the Russian economy is characterized by the proliferation of digital technologies in all spheres of management and public life. As the President of the Russian Federation Vladimir Putin noted in his speech at the UN General Assembly, the necessary tool for solving common world problems is the transition to a digital economy that "sets a new paradigm for the development of the state, the economy and the whole society," which allows using information technologies to increase efficiency managerial decisions [1]. By these days, the Government of the Russian Federation (Order No. 1632-r of July 28, 2017) has approved the program "The Digital Economy of the Russian Federation", in which the creation of the ecosystem of the digital economy of the Russian Federation was cited as the goal [2]. It is understood as the use of digital data to ensure effective interaction between business, the scientific and educational community, the state and its citizens.

In this regard, the purpose of the study is to examine the essence of the digital economy and its role in the process of establishing basic technologies, to identify the directions for the digital transformation of business models, business processes and companies' infrastructure in the way of introducing new technologies and platforms for providing services to consumers in modern economy.

The development of the digital economy calls for the constant progress and improvement of the activities of modern Russian companies. The widespread introduction of five key decisions stimulates digital transformation. These key decisions are:

- Broadband access;

- Data centres;

- Cloud computing centers;

- Large data;

- Internet of things.

The digital era opens up horizons for companies to increase efficiency, mobility and competitiveness based on new technologies. It completes the transfer of all market participants to the united digital world - companies, businesses, consumers, connected objects, which forms new conditions for electronic-network interaction in the market. Digitalization covers an increasing number of companies, industries and regions, translating the actions of employees, processes, products and services into a virtual environment [3].

In 2016, the US Department of Commerce proposed a definition for "digital economy companies". Digital economy companies use technologies such as mobile applications to reduce the number of participants in $\mathrm{p} 2 \mathrm{p}$ transactions; rely on the rating system of user ratings for quality control of services; offer service providers the flexibility to determine their 
working hours; rely on the use of service providers of their own instruments and assets. The US Department of Commerce identified more than 100 organizations that can meet this definition. The list includes the well-known Airbnb, Uber and others.

\section{MATERIALS AND METHODS (MODEL)}

The need for a digital transformation of the company appears when the internal control system is mismatched with higher-level systems and an external "environment" [4]. New digital business models of the company's development will provide additional sources of revenue and competitive advantages, albeit for a short period of time. Therefore, a permanent adjustment of the business model will be required within the framework of the company's developed strategy.

The sustainable development of any organization is possible only if the response speed of the organization's protection system (reference points) is greater than the speed of development of the external threat (digitization rate), that is, the Biesiot indicator, indicator of security (BI) will be more than one:

$$
\mathrm{BI}=\mathrm{CPE} / \mathrm{CPA}
$$

where, CPE is the speed of management or response of the company;

and CPA is the speed of outrage or threat.

The stage-by-stage transformation of the country into an information society is characterized by the use of subindexes of the aggregate index of the development of information and communication technologies (ICT): the first stage is the subindex of access to ICT; the second stage is the subindex of using ICT; the third is the subindex of digital skills.

\section{RESULTS AND DISCUSSION}

Currently, the speed of "digitalization" of Russian society is about $63 \%$ and is constantly growing. Tendencies of Russia's change by subindex are shown in Table 1 .

The first stage - Russia's position in the access subindex is constantly improving, but remains very modest.

The second stage of the country's transformation into information society - ICT intensity is measured by the subindex of using ICT. Judging by the data in Table 1, Russia is gradually moving to the intensive use of ICT, characterized by an increase in the penetration of ICT and mobile broadband services. In 2017, the frequency of Internet use by the population as a percentage of the number of respondents aged 16-72 was $73 \%$, the use of mobile devices for Internet access by the population as a percentage of those aged 16-72 was $49 \%$.
TABLE 1. THE SPEED OF DEVELOPMENT OF THE DIGITAL SOCIETY IN RUSSIA

\begin{tabular}{|c|c|c|c|c|}
\hline \multirow[t]{2}{*}{ Index name } & \multirow{2}{*}{$\begin{array}{l}\text { Unit of } \\
\text { measure of the } \\
\text { index }\end{array}$} & \multicolumn{3}{|c|}{ Year } \\
\hline & & 2015 & 2016 & 2017 \\
\hline \multirow[t]{2}{*}{$\begin{array}{l}1 . \\
\text { Development } \\
\text { Index }\end{array}$} & $\begin{array}{l}\text { Position in the } \\
\text { ranking } \\
\text { (change from } \\
\text { the previous } \\
\text { year) }\end{array}$ & $44(+3) \boldsymbol{\Delta}$ & $\begin{array}{l}43(- \\
1) \nabla\end{array}$ & $\begin{array}{l}45 \quad(- \\
2) \nabla\end{array}$ \\
\hline & Value & 6,83 & 6,95 & 6,96 \\
\hline \multirow[t]{2}{*}{$\begin{array}{l}1.1 \text { Access to } \\
\text { ICT }\end{array}$} & $\begin{array}{l}\text { Rank (change } \\
\text { in rank from } \\
\text { previous year) }\end{array}$ & $47(0) \bullet$ & $\begin{array}{l}49 \quad(- \\
\text { 2) } \nabla^{(-}\end{array}$ & $\begin{array}{l}49 \\
(0) \bullet\end{array}$ \\
\hline & Value & 7,26 & 7,23 & 7,25 \\
\hline \multirow[t]{2}{*}{$\begin{array}{l}\text { 1.2.Use of } \\
\text { ICT }\end{array}$} & $\begin{array}{l}\text { Rank (change } \\
\text { in rank from } \\
\text { previous year) }\end{array}$ & $42(0) \bullet$ & $\begin{array}{l}45 \quad(- \\
3) \nabla\end{array}$ & $\begin{array}{l}44 \quad(- \\
1) \nabla\end{array}$ \\
\hline & Value & 6,23 & 5,87 & 5,78 \\
\hline \multirow[t]{2}{*}{$\begin{array}{l}\text { 1.3. Practical } \\
\text { skills of using } \\
\text { ICT }\end{array}$} & $\begin{array}{l}\text { Rank (change } \\
\text { in rank from } \\
\text { previous year) }\end{array}$ & $14(0) \bullet$ & $\begin{array}{l}14 \\
(0) \bullet\end{array}$ & $\begin{array}{l}14 \\
(0) \bullet\end{array}$ \\
\hline & Value & 8,54 & 8,55 & 8,54 \\
\hline
\end{tabular}

*Compiled and calculated by the authors on the basis of materials: Measuring the Information Society 2015, p. 28,31,36,45; Measuring the Information Society 2016, p. 30,45-46; International Telecommunication Union: The ICT Development Index 2017

The third stage of the transformation of the country into information society - ICT impact - shows the socio-economic effects achieved as a result of the use of ICT. This stage largely depends on the level of ICT skills achieved in society, which is measured by the subindex of the skills of the aggregate ICT index (see Table 1). This subindex reflects the opportunities of the society to optimize the results of ICT introduction: the level of the existing skills in the society determines the optimality and completeness of attracting the potential of ICT for socio-economic development. By the level of ICT skills, Russia is still at an early stage of development with an estimate of 8.5.

As for the level of digitalization of Russian companies, it also remains low [5] (see Fig 1).

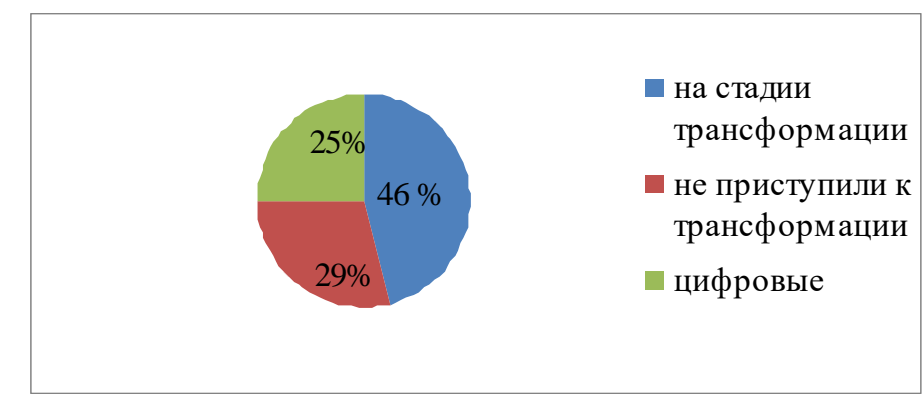

Fig.1. Level of digitization of Russian companies

Blue - companies at the stage of transformation,

Red - companies have not started its transformation yet, Green - digital companies. 
As shown in Figure 1, only $29 \%$ of companies are considered digital, $46 \%$ are at the stage of transformation and $29 \%$ have not yet begun to "digitize". The main criterion for dividing companies is the level of IT-budgeting for digital business transformation. Among the digital companies are PJSC Gazprom, PJSC Sberbank of Russia, PJSC Lukoil - the cost of their digitalization is $\$ 160$ billion per year.

The directions and objectives, which are digitized in Russian companies, include: the use of the Internet, including broadband, the use of Web sites, cloud services, ERP and CRM systems, the use of the Internet for the purchase / sale of goods, works, services. Dynamics of development of these areas of "digitalization" of companies is presented in Table 2.

\section{TABLE 2. DYNAMICS OF DIGITALIZATION DEVELOPMENT IN COMPANIES}

\begin{tabular}{|c|c|c|c|c|}
\hline \multirow{2}{*}{$\begin{array}{l}\text { Directions for the } \\
\text { development of } \\
\text { digitalization }\end{array}$} & \multirow[b]{2}{*}{$\begin{array}{c}\text { Units } \\
\text { of } \\
\text { meas } \\
\text { urem } \\
\text { ent }\end{array}$} & \multicolumn{3}{|c|}{ Year } \\
\hline & & 2015 & 2016 & 2017 \\
\hline Use of the Internet & \multirow{8}{*}{$\begin{array}{l}\% \text { of the } \\
\text { total } \\
\text { number of } \\
\text { companies } \\
\text { of the } \\
\text { business } \\
\text { sector }\end{array}$} & 85 & 85 & 86 \\
\hline $\begin{array}{l}\text { Use of broadband } \\
\text { Internet }\end{array}$ & & 79 & 77 & 79 \\
\hline $\begin{array}{l}\text { Companies having } \\
\text { websites }\end{array}$ & & 41 & 42 & 41 \\
\hline $\begin{array}{l}\text { Companies using } \\
\text { cloud services }\end{array}$ & & 18 & 18 & 18 \\
\hline $\begin{array}{l}\text { Companies using } \\
\text { CRM-systems }\end{array}$ & & 13 & 13 & 13 \\
\hline $\begin{array}{l}\text { Companies using } \\
\text { ERP-systems }\end{array}$ & & 15 & 16 & 17 \\
\hline $\begin{array}{l}\text { Companies using } \\
\text { the Internet to } \\
\text { purchase goods, } \\
\text { works, services }\end{array}$ & & 17 & 18 & 19 \\
\hline $\begin{array}{l}\text { Companies using } \\
\text { the Internet to sell } \\
\text { goods, works, } \\
\text { services }\end{array}$ & & 12 & 12 & 12 \\
\hline
\end{tabular}

Compiled by the authors on the materials: Indicators of the digital economy 2016 and 2017. [Electronic resource] URL: https://www.hse.ru/primarydata/iio. - (circulation date 04.01.2018)

According to the data obtained in Table 2, the "digitization" of Russian companies is at a low level. Internet resource for economic activity is used in less than $40 \%$ of possible situations.

Accordingly, using the obtained data in Table. 1 and Table 2, we can calculate the Biesiot indicator [6] (ПБ) (see Table $3)$.
TABLE 3. BIESIOT INDICATOR (BI) IN RUSSIA IN 20152017

\begin{tabular}{|c|c|c|}
\hline BI in 2015 & BI in 2016 & BI in 2017 \\
\hline $20 / 52=0,38$ & $21 / 60=0,35$ & $29 / 63=0,46$ \\
\hline
\end{tabular}

Despite the fact that the Biesiot indicator has turned out to be less than one, the speed of response of the company's management system remains less than the speed of "digitalization" of the society. It can be concluded that at present there is a need to increase the level of "digitalization" of Russian companies.

The development of digital companies in the modern economy requires: firstly, improving the management of the organization in the direction of active use of ICT; secondly, creation of a unique innovation base; Thirdly, virtualization of business processes in the form of network interaction with customers (CRM-systems), suppliers, employees, - it is necessary to involve the interested parties in creating value for business, to evaluate and improve the quality of the company's services; Fourthly, enrichment of the basic processes, adapting them to new opportunities and challenges of the changing world on the basis of analysis of the trends in the digital economy, increment of accumulated experience and knowledge; Fifthly, the replacement of low-skilled labour force with "digital personnel" with a high level of IT competence, who are able not only to use ICT in their work, but also to perform analytical work (more than $50 \%$ of the time), improvise, work in conditions of uncertainty, making decisions that have a high level of education, a long cycle of preparation and a broad outlook; Finally, constant analysis and building up its positions in rankings, forums and chats, - it is necessary to consider them as a source of competitive advantages, to note the growth in revenues from the use of ICT in the total revenue share and to strive to increase it.

\section{CONCLUSION}

The analysis of the factors made it possible to identify threats and incentives for the development of "digitalization" of companies in Russia. are:

The factors restraining the "digitalization" of companies

\section{$\bullet$}

Complicated access to participation in competitive selection of projects and venture financing in the regions (the necessary infrastructure is not created and equal conditions for applicants are not ensured (according to the RVCA, $83 \%$ of the volume of venture investments for 2016 was for companies located in the Central Federal District) );

- Low efficiency of start-ups selection, there is no established multi-level system of project financing;

- $\quad$ Lack of conditions for retaining qualified specialists and business in the country, as well as attracting foreign investors to Russia; 
$\bullet$

Underdevelopment of accelerators, business incubators and special economic zones, mechanisms for additional tax incentives to stimulate demand for innovation on their part;

- $\quad$ Lack of regulatory and legal framework for crowd-funding platforms [7].

Factors that stimulate the development of "digitalization" of companies include:

- $\quad$ Increase of the contribution of digitalization to the country's GDP [8]. The country's GDP grew by $7 \%$ from 2011 to 2015, and the volume of the digital economy increased by $59 \%$ over the same period - by 1.2 trillion rubles in prices of 2015. Thus, in these five years, the digital economy accounted for $24 \%$ of the total GDP growth;

- Multiple positive examples of the development of start-ups (Yandex, "Tinkoff Bank", Mail.ru, "VKontakte");

- $\quad$ Successful implementation of the largest digital infrastructure projects "Our city" and "Active citizen";

- $\quad$ Enhancing Russia's access to broadband

Internet;

Presence of an intellectual and scientific base in the country, supported by a good system of secondary and higher technical education;

- Active development of a countrywide ICT

infrastructure;

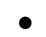

Awareness of the state importance of these tasks by state authorities and the ability to mobilize resources all through the country to address them.

Thus, we can conclude that the basis for effective "digitization" of companies is: a developed telecommunications infrastructure; growth of investments in specific human capital (i.e. knowledge, skills, including those which can be used only at a certain workplace or only in a particular company), increasing the accumulation of intangible assets and creating clusters around an efficient high-tech enterprise; reliance on their own innovations [9].

\section{PROSPECTS FOR RESEARCH}

In the framework of further research, the internal "digital" potential of companies will be evaluated. In particular, it is of interest to carry out an evaluation of the personnel potential of companies, since the improvement of the "digital" skills of personnel is extremely necessary and has important consequences. On the consumer side, it determines the degree of satisfaction of his needs; on the part of the employee - his competitiveness in the search for work. The development of the digital economy in the automation of the processes of creating various benefits, on the one hand, creates a kind of competition between the consumer and the employee for the performance of production functions, on the other hand, balances their roles in the performance of these functions.

\section{References}

[1] Vladimir Putin's speech at the plenary session of SPIEF-17 [Electronic resource] URL: // http: //eanews.ru/news/policy/Vladimir_Putin_vystupil_na_Peterburgskom_ekono micheskom_forume_STENOGRAMMA_02_06_2017/ - (circulation date 12.01.2018)

[2]. Order of the Government of the Russian Federation of July 28, 2017 No. 1632-r "On the approval of the program" Digital Economy of the Russian Federation "[Electronic resource] URL: http: //static.government.ru/media/files/9gFM4FHj4Ps.pdf - date 12.01.2018)

[3] Avdeeva I.L. Analysis of the prospects for the development of the digital economy in Russia and abroad / Digital Economy and Industry 4.0: Problems and Prospects: Proceedings of the Scientific and Practical Conference with International Participation, Ed. Dr. econ. Sciences, prof. A.V.Babkina. - SPb .: Publishing house of Polytechnic. University, 2017. - P. 19-22.

[4] Ilyinskii, V. V. Business Modelling and Information Technologies in the Digital Economy / V. V. Ilyinsky, N. V. Pereborova // Digital Transformation of Economics and Industry: Problems and Perspectives Ed. A.V. Babkin. - St. Petersburg: Publishing house Polytechnic. un-ta. -2017.pp. 636-665.

[5]. Digital organizations: trends and practices of use in Russia [Electronic resource] URL: http://www.riarating.ru/infografika/20160127/630007042.html.-(date of circulation 01/01/2018)

[6] Ilyinskaya E.M, Ilyinskii V.V. / World scientific and technological trends 2017 [Electronic resource] URL: http://sworld.com.ua/konferger1/16.pdf - (circulation date 04.01.2018)

[7] Digital Russia report 2017 [Electronic resource] URL: www.tadviser.ru/images/c/c2/Digital-Russia-report.pdf - (circulation date $12 / 01 / 2018)$

[8] Kadomtseva S.V., Manakhova I.V. The modern paradigm of socioeconomic development: Part 1: Information revolution // Bulletin of the Saratov State Social and Economic University. - 2017. No. 5 (69).

[9] Belova L.G., The essence of the information society and the paradigm of civilization development // Audit and financial analysis. - 2014. - No. 4. - P. 315-321. 